\title{
SUMMER 2010
}

\section{The}

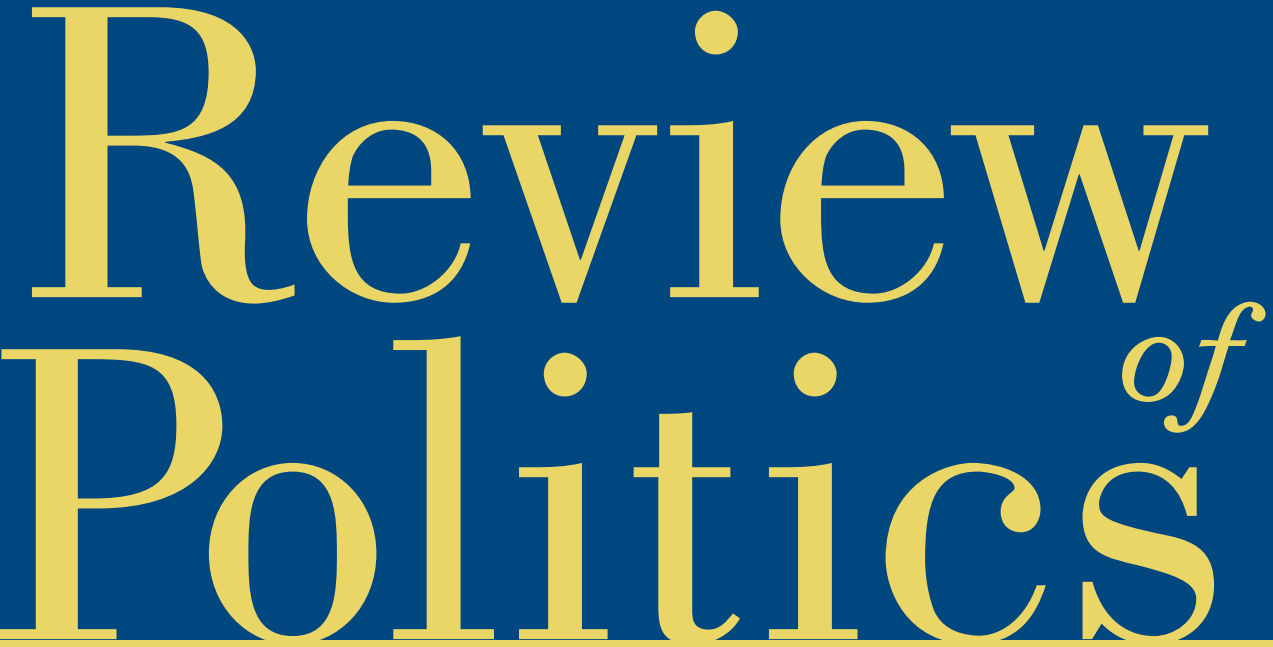

ARTICLES

David Janssens, "Easily, At a Glance: Aristotle's Political Optics"

Daniel R. Brunstetter, "Sepúlveda, Las Casas, and the Other:

Exploring the Tension between Moral Universalism and Alterity"

Jennifer Einspahr, "The Beginning that Never Was: Mediation and Freedom in Rousseau's Political Thought"

Jonathan D. Marks, "Rousseau's Use of the Jewish Example"

RobertLamb, "Liberty, Equality, and the Boundaries of Ownership:

Thomas Paine's Theory of Property Rights"

Review Essay: Ernesto Verdeja, "Genocide: Clarifying Concepts and Causes of Cruelty" 


\title{
THE REVIEW OF POLITICS
}

\author{
Editor \\ CATHERINE H. ZUCKERT \\ Executive Associate Editor \\ DENNIS WM MORAN \\ Book Review Editor \\ PETER R. MOODY, JR. \\ Assistant Editor \\ LES HARRIS \\ Editorial Interns: \\ Joshua M. Bandoch \\ Andrew W. Bramsen \\ Associate Editors
}

Fred Dallmayr

E.A. Goerner

A. James McAdams

Ruth M. Abbey

Daniel Philpott

James Turner

Former Editors

Waldemar Gurian

M.A. Fitzsimons

Thomas Stritch

Frederick J. Crosson

Donald P. Kommers

Walter Nicgorski

Editorial Advisory Board

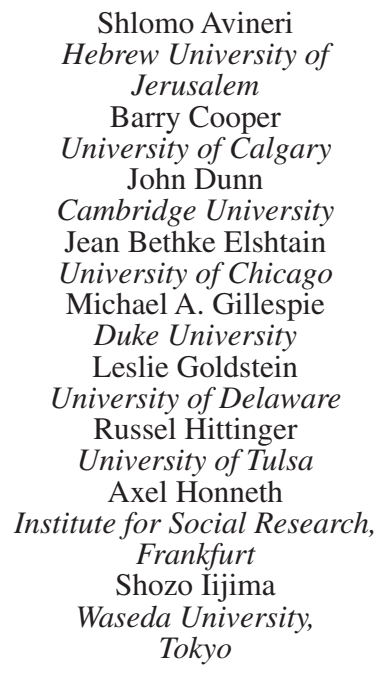

Ramin Jahanbegloo

University of Toronto Pierre Manent

L'Ecole des Hautes Etudes en sciences sociales

Harvey C. Mansfield

Harvard University Mary Nichols Baylor University

Bruce M. Russett Yale University

Arlene Saxonhouse

University of Michigan

Steven B. Smith

Yale University

Peter Steinberger

Reed College

John Witte, Jr.

Emory University

Jean M. Yarbrough

Bowdoin College

Administrative Assistant: Kelli Brown

The Review of Politics publishes primarily philosophical and historical studies of politics, especially those concentrating on political theory and American political thought. The journal also includes thoughtful scholarly reflections on all aspects of politics-including analysis of institutions and techniques, international relations, comparative politics, literary reflections on politics or political interpretations of literary works, constitutional theory and practices. 


\section{TABLE OF CONTENTS SUMMER 2010}

Vol. 72

SUMMER 2010

No. 3

David Janssens

Easily, At a Glance: Aristotle's Political Optics . . . . . . . . . 385

Daniel R. Brunstetter

Sepúlveda, Las Casas, and the Other: Exploring the Tension

between Moral Universalism and Alterity ............ 409

Jennifer Einspahr

The Beginning that Never Was: Mediation and Freedom in

Rousseau's Political Thought ................ 437

Jonathan D. Marks

Rousseau's Use of the Jewish Example . . . . . . . . . . 463

Robert Lamb

Liberty, Equality, and the Boundaries of Ownership: Thomas

Paine's Theory of Property Rights . . . . . . . . . . . 483

Review Essay:

Ernesto Verdeja

Genocide: Clarifying Concepts and Causes

of Cruelty

Reviews:

G. Robert Blakey: RIGHT AND CONSCIENCE

Review of Harold H. Bruff's Bad Advice: Bush's

Lawyers in the War on Terror. . . . . . . . . . . . . . . . . 527

Ben Saunders: AMBIGUOUS ACCOUNTABILITIES

Review of Valerie Sperling's Altered States:

The Globalization of Accountability . . . . . . . . . . . . . . 530

Thomas M. Hawley: THE POLITICS OF LOSS

Review of Michael J. Allen's Until the Last Man Comes

Home: POWs, MIAs, and the Unending Vietnam War . . . . . 533

Stephen F. Knott: LOW BLOWS AGAINST PROGRESSIVE DELUSIONS

Review of Angelo M. Codevilla's Advice to War

Presidents: A Remedial Course in Statecraft . . . . . . . . . . . 535 
Gerald J. Russello: STILL UNEXPLAINED

Review of Frank J. Colucci's Justice Kennedy's

Jurisprudence: The Full and Necessary Meaning of Liberty . . 538

John Francis Burke: MULTIPLE RATIONALITIES

OF JUSTICE

Review of Amartya Sen's The Idea of Justice . . . . . . . . . . 540

Paul O. Carrese: A PHILOSOPHICAL HISTORY

OF PROPHETIC WARNINGS AND PUGNACITY

Review of Paul A. Rahe's Soft Despotism, Democracy's Drift:

Montesquieu, Rousseau, Tocqueville, and the

Modern Prospect. . . . . . . . . . . . . . . . . . . . . . . 542

Karlyn Kohrs Campbell: TRUTHS OF PERSUASION

Review of Michael S. Kochin's Five Chapters on Rhetoric:

Character, Action, Things, Nothing, and Art . . . . . . . 546

Peter K. Bol: THE FOUNDATION OF TRADITIONAL

CHINA

Review of Dieter Kuhn's The Age of Confucian Rule:

The Song Transformation of China . . . . . . . . . . . . . 548

Janice Liedl: CONSTRUCTING ROYAL SUPREMACY

Review of J. Patrick Coby's Thomas Cromwell:

Machiavellian Statecraft and the English Reformation. . . . . . 550

Antony Black: MEDIEVAL THOUGHT AND THE

DEFECTS OF MODERNITY

Review of Cary J. Nederman's Lineages of European

Political Thought: Explorations along the Medieval/

Modern Divide from John of Salisbury to Hegel . . . . . . . . . 553

Grant Kaplan: FAITH, REASON, MODERNITY

Review of John J. Ranieri's Disturbing Revelation:

Leo Strauss, Eric Voegelin, and the Bible . . . . . . . . . . 555

Peter Brickey LeQuire: GOING BEYOND THE LIMITS

Review of Barry Cooper's Beginning the Quest: Law and

Politics in the Early Work of Eric Voegelin . . . . . . . . . . . 557

Shannon Mariotti: COMMUNICATING TO THE DEMOS

Review of Gerhard Schweppenhäuser's Theodor W. Adorno:

An Introduction. Trans. James Rolleston . . . . . . . . . . . . . 561

Wooyeal Paik: LEADING TO THE POLITICS OF SPORTS

Review of Mark Golden's Greek Sport and Social Status . . 563

Andrew Zimbalist: COMMERCIALIZED AND

PROFESSIONALIZED

Review of Michael Oriard's Bowled Over: Big-Time

College Football from the Sixties to the BCS Era......... . 566 


\section{CONTRIBUTORS TO THIS ISSUE}

DAVID JANSSENS is Assistant Professor of Humanities at Tilburg University, the Netherlands. DANIEL R. BRUNSTETTER is Assistant Professor of Political Science in the School of Social Sciences at the University of California, Irvine. JENNIFER EINSPAHR is Associate Professor of Political Science and Women's Studies at Kalamazoo College. JONATHAN D. MARKS is Associate Professor of Politics at Ursinus College. ROBERT LAMB is Senior Lecturer in Political Philosophy at the University of Exeter.

ERNESTO VERDEJA is Assistant Professor of Political Science and Peace Studies at the Kroc Institute for International Peace Studies at the University of Notre Dame. G. ROBERT BLAKEY is William J. and Dorothy K. O'Neill Professor of Law at the University of Notre Dame. BEN SAUNDERS is Faculty Lecturer in Philosophy at the University of Oxford. THOMAS M. HAWLEY is Associate Professor of Government at Eastern Washington University. STEPHEN F. KNOTT is Associate Professor of National Security Studies at the United States Naval War College. GERALD J. RUSSELLO of Counsel at Bingham McCutchen, LLP. JOHN FRANCIS BURKE is Professor of Political Science at the University of St. Thomas. PAUL O. CARRESE is Professor of Political Science at the U.S. Air Force Academy. KARLYN KOHRS CAMPBELL is Professor of Communication Studies at the University of Minnesota. PETER K. BOL is Charles H. Carswell Professor of East Asian Languages and Civilizations at Harvard University. JANICE LIEDL is Associate Professor of History at Laurentian University. ANTONY BLACK is Emeritus Professor in the Politics Programme, University of Dundee. GRANT KAPLAN is Assistant Professor in the Department of Theological Studies at Saint Louis University. PETER BRICKEY LeQUIRE is a Postdoctoral Candidate in the Committee on Social Thought at the University of Chicago. SHANNON MARIOTTI is Assistant Professor of Political Science at Southwestern University. WOOYEAL PAIK is 
Postdoctoral Fellow at the Institute of Development and Human Security, Ewha Womans University, Seoul, South Korea. ANDREW ZIMBALIST is Robert A. Woods Professor of Economics at Smith College. 
Subscription Information: The Review of Politics (ISSN 0034-6705) is published quarterly in February, May, August and November by Cambridge University Press, 32 Avenue of the Americas, New York, NY 10013-2473 USA/The Edinburgh Building, Shaftesbury Road, Cambridge CB2 8RU, UK for the University of Notre Dame. Annual subscription rates for Volume 72 (2010): Institutional subscription rates, print and online: US $\$ 120.00$ in the USA, Canada, and Mexico; UK $£ 68.00+$ VAT elsewhere. Institutional subscription rates, online only: US \$109.00 in the USA, Canada, and Mexico; UK $£ 58.00$ + VAT elsewhere. Institutional subscription rates, print only: US $\$ 115.00$ in the USA, Canada, and Mexico; UK $£ 62.00+$ VAT elsewhere. Individual subscription rates, print only: US $\$ 36.00$ in the USA, Canada, and Mexico; UK $£ 18.00$ + VAT elsewhere. Correspondence concerning subscriptions should be sent to: Cambridge University Press, 100 Brook Hill Drive, West Nyack, NY 10994, USA for customers in the USA, Canada, or Mexico. Customers elsewhere should contact: Cambridge University Press, The Edinburgh Building, Shaftesbury Road, Cambridge CB2 8RU, UK.

Editorial Office: All correspondence concerning submissions and manuscripts under review should be sent to The Review of Politics, University of Notre Dame, 547 Flanner Hall, Notre Dame, IN 46556. Phone: 574-631-6623. Email: ROP.Editor.1@nd.edu. Website: www.nd.edu/ rop

Abstracting and Indexing Information: Articles in The Review of Politics are indexed in the International Index to Periodicals and the Catholic Periodicals and Literature Index; abstracted in the International Political Science Abstracts; and abstracted and indexed in ABC POL. SCI., Historical Abstracts, Social Science Index (also available in the electronic versions), Book Review Index, and International Bibliography of the Social Sciences.

Copyright (C) 2010 University of Notre Dame. All rights reserved. No part of this publication may be reproduced, in any form or by any means, electronic, photocopy, or otherwise, without permission in writing from Cambridge University Press, Rights and Permissions Manager, 32 Avenue of the Americas, New York, NY 10013-2473 USA. For further information see http://us.cambridge/org/information/rights/.

Periodicals postage paid in New York, NY and additional mailing offices. Postmaster: Send address changes to The Review of Politics, Cambridge University Press, 100 Brook Hill Drive, West Nyack, NY 10994-2133 USA.

Photocopying information for users in the U.S.A.: the Item-Fee Code for the publication (0034-6705/10 \$9.00 +.10) indicates that copying for internal or personal use beyond that permitted by Sec. 107 or 108 of the U.S. Copyright Law is authorized for users duly registered with the Copyright Clearance Center (CCC) provided that the appropriate remittance of $\$ 9.00$ per article is paid directly to CCC, 222 Rosewood Drive, Danvers, MA 01923. Specific written permission must be obtained for all other copying. 